\title{
Za dialektoložkou Stanislavou Kloferovou
}

Kdykoli kdokoli z kolegů nebo studentů potřeboval radu týkající se problematiky českých nářečí, mohl se s důvěrou obrátit na doktorku Kloferovou a věděl, že se mu dostane spolehlivé odpovědi, navíc podané s taktem a prátelskou laskavostí dobrého člověka. Jen velmi těžko se lze vyrovnat se skutečností, že nás Stanislava Kloferová 5. července 2020 předčasně a navždy opustila. Česká lingvistika ztratila vynikající dialektoložku, jednu z největších znalkyň české, ale i německé nářeční problematiky, velmi pracovitou a přitom mimořádně skromnou badatelku, jejíz stále rostoucí odborné kvality zúročovaly celoživotní zaujetí pro milovaný obor.

PhDr. Stanislava Kloferová, CSc., se narodila 3. 11. 1955 v Přerově, většinu svého života však prožila v Brně, kde absolvovala i středoškolské a vysokoškolské vzdělání. Už na gymnáziu motivovala její zájem o český jazyk výborná středoškolská profesorka Jarmila Večerková, na Filozofické fakultě tehdejší Univerzity Jana Evangelisty Purkyně, kde Stanislava Kloferová vystudovala dvouobor čeština a němčina, pak její budoucí odbornou profilaci ovlivnili zejména vynikající bohemisté profesor Dušan Šlosar, profesorka Zdenka Rusínová a profesorka Marie Krčmová. Při vstupu na profesní dráhu se jejími učiteli a zároveň kolegy stali přední dialektologové doktor Jan Balhar, doktor Slavomír Utěšený a doktor Pavel Jančák. Původně se sice tato žačka profesora Zdeňka Masař́ka chtěla věnovat germanistice, jak o tom svědčí ještě její diplomová práce, studijní pobyt v dialektologickém oddělení Ústavu pro jazyk český ČSAV však obrátil její odborný zájem k českým nářečím, která se pak bez nadsázky stala její životní láskou. Ani druhý vystudovaný obor ale doktorka Kloferová neopustila, kvalitní germanistické školení využila při svém výzkumu česko-německých jazykových kontaktů.

S dialektologickým oddělením Úč byla Stanislava Kloferová spjata 35 let, od roku 1982 až do svého nečekaného odchodu (s výjimkou tř́letého lektorátu na Vídeňské univerzitě v letech 2000 až 2003). V brněnské pobočce Úč také absolvovala vědeckou výchovu a na základě obhájení dizertace Jazyková situace v nově dosídleném severomoravském pohraničí, jejíž kvalita byla oceněna cenou Českého literárního fondu, získala v roce 1991 titul CSc. Stala se kmenovou členkou dialektologického pracoviště (v letech 1993 až 2000 zastávala funkci vedoucí) a významně se podílela na všech jeho výzkumných i publikačních projektech. Vzrůstající relevanci odborného působení Stanislavy Kloferové v Úč lze dokumentovat vývojem její účasti na zásadní 
práci moderní české dialektologie Českém jazykovém atlasu (díly 1-5: 1992, 1997, 1999, 2002, 2005; svazek Dodatky: 2011). V prvním dílu ČjA autorsky zpracovala 5 položek a na jedné další se podílela, ve druhém a třetím dílu už 20 a 28 položek a ve čtvrtém dílu 40 položek. Pro pátý díl vedle zpracování 2 položek připravila zejména neobyčejně významnou kapitolu Svazky izoglos v nářečích, v níž shrnutím podkladů z celého ČjA objevně posunula dosavadní představy o nářeční diferenciaci českého jazykového prostoru. Výrazně se podílela i na závěrečném dodatkovém svazku ČJA. Platným členem autorského kolektivu byla Stanislava Kloferová také v rámci budování Slovníku pomístních jmen na Moravě a ve Slezsku, jehož hesla jsou od roku 2014 zveřejňována na webových stránkách UjČ AV ČR. Klíčový byl její podíl na rozpracovaném Slovníku náreč́i českého jazyka, rovněž zveřejňovaném na stránkách ÚjČ AV ČR. Zejména pro tento rozsáhlý projekt, na jehož koncepci se Stanislava Kloferová zásadním způsobem podílela, znamená její odchod těžkou ztrátu. Chybět ale bude i ve všech dalších kolektivních úkolech dialektologického oddělení ÚJČ, v neposlední řadě v činnostech popularizačních, $\mathrm{k}$ jejichž úspěchu výrazně přispívaly její nápadité, odborně pečlivě zpracované a jemným humorem okořeněné stati. Charakteristická fráze Stanislavy Kloferové „na okraj dodejme“ přinesla často i v populárně laděném textu zcela objevnou dialektologickou informaci (naposled v roce 2018 v knížce Život ve slovech, slova v životě. Procházka labyrintem českých náreč́i).

Šíře badatelských a publikačních aktivit doktorky Kloferové se však neomezila pouze na kolektivní díla dialektologického oddělení. Metodologickou a znalostní průpravu, kterou získala při jejich př́pravě, využila v celé řadě svých prací individuálních, případně vzniklých na základě kooperace s dalšími domácími nebo zahraničními lingvisty a institucemi. Tematickou pestrost, rozsah a význam odborné činnosti Stanislavy Kloferové dokumentuje soupis jejích publikačních výsledkủ čítající 237 položek. Svědčí mj. o tom, že v době přerušení badatelské práce byla tato přední česká dialektoložka na vrcholu svých tvůrčích sil.

Ze široké škály témat, jimž se Stanislava Kloferová věnovala, připomeňme alespoň několik, na něž se zaměřila nejvýrazněji. $V$ první fázi její výzkumné práce k nim patřilo formování běžné mluvy poválečného osídlení severní Moravy, jednoho z jazykově nejkomplikovanějších území českého národního jazyka. Tuto látku, jíž se zabývala už ve své dizertaci a později v řadě dalších studií, Staňa Kloferová nejkomplexněji zpracovala v monografii Mluva $v$ severomoravském pohraničí (2000). Jmenovanou monografii, o níž lze říci, že přinesla definitivní vhled do sledované problematiky, charakterizují všechny základní rysy autorčiny výzkumné práce: úcta $\mathrm{k}$ jazykové materii, až úzkostlivě pečlivé vyhodnocování každého detailu, ale zároveň schopnost nadhledu a zobecnění, a také silný sebekritický autoregulativ. Českou dialektologii Stanislava Kloferová významně obohatila i zmíněným zpracováním a interpretací vrstvení izoglos v ČjA. Propojením 1600 mapových obrazů (tehdy ještě bez pomoci počítačových nástrojů) odhalila 60 izoglosových svazků diferencujících nářeční oblasti českého národního jazyka. $\mathrm{V}$ podstatě poprvé byly 
reflektovány též hranice lexikálních jevů. Vyhodnocením zjištěných dat, opřeným o důkladnou znalost dialektů i studium historických souvislostí a determinací, doktorka Kloferová zpřesnila a v mnohém objevně doplnila dosavadní poznatky o nářečních předělech a celkovém areálovém členění na českém jazykovém území. Také dalšími svými pracemi opřenými o materiál ČJA se Kloferová inspirativně zasloužila o badatelské využití údajů shromážděných a prezentovaných v tomto výjimečném díle jazykového zeměpisu.

Pravděpodobně stěžejním a v průběhu života stále akcentovanějším tématem výzkumné práce Stanislavy Kloferové se staly česko-německé nářeční kontakty. Tento směr byl předurčen už její dvouoborovou kvalifikací a výrazně posílen studijními pobyty v německé jazykové oblasti, zejména v Institutu für deutsche Sprache, Deutscher Sprachatlas, v německém Marburgu (1996). Velmi dobré kontakty měla doktorka Kloferová také s Institutem für Slawistik der Universität Wien. Díky renomé, které si získala fundovaným zpracováním otázek kontaktové a areálové lingvistiky, byla opakovaně zvána i k účasti na mezinárodních projektech.

Po celý život doktorka Kloferová úzce spolupracovala také s bohemisty své mateřské fakulty. Dlouhodobě působila na Letní škole slovanských studií, kde se od začátku 80. let do přelomu tisíciletí věnovala výuce češtiny pro cizince $\mathrm{z}$ německy mluvících oblastí. Od 9o. let do roku 2013 pro LŠSS připravovala značně oblíbené odborné přednášky o češtině a českých dialektech, z nichž většina je pro svou obsažnost a zároveň výkladovou srozumitelnost užívána i při výuce českých studentů (např. Jak se mluví na Moravě, 2005; Překážet, nebo zavazet? K nářečním jevům v soudobé češtině, 2013). Stanislava Kloferová se významně uplatňovala též jako vyučující v bakalářských a magisterských programech českého jazyka a literatury. Její doménou byly pochopitelně semináře s dialektologickou tematikou, které vyučovala až do svého odchodu, v 9o. letech se však podílela také na výuce morfologie a slovotvorby. Značný význam mělo její odborné vedení diplomových prací, které díky obětavosti, času a entuziasmu, jež do této činnosti vkládala, patřily vždy k těm nejkvalitnějším. Doktorka Kloferová byla také výbornou školitelkou doktorandů a stálou členkou oborové komise doktorského studijního programu Ústavu českého jazyka.

Stanislava Kloferová se podílela i na řadě odborných a publikačních aktivit Ústavu českého jazyka FF MU. Nejenže přispívala do fakultního jazykovědného sborníku a do konferenčních a jubilejních sborníků redigovaných ÚČJ FF MU, ale přijala také účast v zásadních projektech tohoto pracoviště, $\mathrm{k}$ nimž patřil Encyklopedický slovník češtiny (2002, Kloferová zpracovala 15 hesel, z toho 3 jako spoluautorka), Kapitoly z dějin české jazykovědné bohemistiky (2007, Kloferová zpracovala kapitolu Dialektologie) a Nový encyklopedický slovník češtiny (2016, Kloferová zpracovala 16 hesel, z toho 3 jako spoluautorka). V uvedených kompendiích mj. uplatnila další svoji tematickou orientaci, jíž byl celkový náhled na česká nářečí a na vývoj české dialektologie. Jako přední představitelku této disciplíny v českém prostoru, ale též jako 
ochotnou, pracovitou a spolehlivou pracovnici, zvali doktorku Kloferovou ke ztvárnění přehledových hesel s dialektologickou problematikou i redaktoři dalších českých a zahraničních publikací encyklopedického charakteru.

$\mathrm{PhDr}$. Stanislava Kloferová, CSc., byla bohemistickému pracovišti brněnské filozofické fakulty po celý život velmi blízká a významně přispívala $k$ utváření přátelských vztahů mezi jeho členy a kolegy z dialektologického oddělení AV ČR. Jejím odchodem ztrácí Ústav českého jazyka FF MU dlouhodobou externí spolupracovnici, která se velkou měrou podílela na jeho výzkumných a publikačních projektech a svým pedagogickým působením dokázala získat mnoho mladých lidí pro studium českých dialektů a češtiny vůbec. Kolegy i studenty motivovala nejen odborným rozhledem, precizností výzkumné práce, vstřícností a ochotou podat vždy pomocnou ruku, ale také tím, že kolem sebe šírila optimismus a přátelský humor. Tak si naši Staňu budeme pamatovat a s vděčností na ni vzpomínat.

Za učitele a studenty brněnské bohemistiky na FF MU

\section{Zdeňka Hladká}

Department of Czech Language

Faculty of Arts, Masaryk University

Arna Nováka 1, 602 oo Brno

Czech Republic

zdena@phil.muni.cz 